\title{
Demographic and social trends affecting intergenerational relations in the MENA region
}

International Institute of Social Studies, Erasmus University, Rotterdam, Netherlands meskoub@iss.nl http://dx.doi.org/10.5339/ difi.2013.arabfamily.9

(C) 2013, Meskoub, licensee Bloomsbury Qatar Foundation Journals. This is an open access article distributed under the terms of the Creative Commons Attribution license CC BY 3.0, which permits unrestricted use, distribution and reproduction in any medium, provided the original work is properly cited.

Mahmoud Meskoub

\begin{abstract}
This paper focuses on poverty in the MENA region and whether it can be alleviated by intergenerational support within and across households. Intergenerational relations are mediated through several institutions. The most prominent of these are households, state, civil society and market. Combinations of social arrangements, economic resources and cultural traditions govern these institutions. Whether or not family and households can provide the necessary supports for their poorer or disadvantaged members would crucially depend on household composition, its economic resources and its interaction with the institutions of state, civil society and market. This paper also explores the trends in family formation and composition over time and household interaction with the above mentioned institutions through the labour market, or through various state and NGO driven welfare programmes. The above trends as well as migration impact the intergenerational support within families. This paper will argue for improved social support and regional integration in order to complement family resources as well as tackle some of the emerging issues in relation to population ageing and care economy in the region.
\end{abstract}

\section{Introduction}

The MENA region has been experiencing two important demographic phenomena in the past few decades. One is the gradual and sustained decline in fertility and the other is the high rate of migration. Both have focused attention on intergenerational linkages at micro/household/ family level as well as macro and meso social levels. A declining fertility leads to population ageing and warrants attention as to the need for long term planning to manage its social and economic implications through intergenerational support. Moreover, intergenerational support has also come under scrutiny because of the impact of the national and international migration on population ageing.

The backdrop to the changing demography of MENA is the complex set of countries in the region that have to develop social and economic policies in the next 20 years if they were to be prepared for the challenges of population ageing, migration and intergenerational support. This paper will explore some of the key social and economic issues facing the region by locating the intergenerational support in the broader issue of social production and re-production and the importance of intergeneration support for it. It would then provide an overview of some of the key demographic developments such as fertility and mortality decline, demographic transition,

Meskoub M. Demographic and social trends affecting intergenerational relations in the MENA region, DIFI Family Research and Proceedings 2013, Special issue on "Protecting the Arab Family from Poverty: Employment, Social Integration and Intergenerational Solidarity" 2013:9 http://dx.doi.org/10.5339/difi.2013.arabfamily.9 
family formation and migration. Finally, broad policy options for managing the intergenerational relationship and the more general welfare issues in the face of demographic changes in the region and levels of economic and social resources available in different countries.

\section{Generations and inter-generational support and why it matters.}

Production and reproduction are at the heart of economic and social life of any society. Historical developments and resource base shape the way a society's production and reproduction are organized, which is about the relationship between generations at micro and macro levels. Inter-generational relationship is by definition social, and it is this social relation that shapes the social production and re-production of the society. Any society has to produce/ generate itself economic and social level (including cultural production) whilst to ensure its survival it has to be re-produced as well.

The economic and productive system of any society will bring together its productive forces of, for example, labour, land and other natural resources as well as capital. That requires social relations among different groups of population. An important aspect of social relations is property rights that govern the ownership of means of production and organise the relationship between different classes and groups of people, some of whom own the means of production and others that do not. And that sets the foundation for different claims over the output produced. In other words, distribution of national income is, in principle, an outcome of the property rights over resources of the economy. Since the industrial revolution, the development of capitalist relations and the emergence of nation states all countries use a mix of market and state control to organise their production and distribution. The reasons for the development of and the balance between market and state control does not concern us here, but it is important to note that an understanding of generational issues in terms of 'production' and 'reproduction' of labour and access to resources, through distribution of output and inheritance rights are crucial for the analysis of economic and social relations.

In any economic and social system the interaction between generations takes place in private (at the level of household and family) and public spheres (at the level of different communities and nation). The two spheres build and dependent on each other.

For example national tax and subsidy policies affect household income and capacity to take care of its members. On the other hand and more important, it is the private sphere that act as the foundation of public sphere. Production and maintenance of labour power through, for example, child-bearing and childcare, and reproduction of labour through food production at home and care of the sick, as well as the social reproduction through transfer of social norms, cultures and mores of society. (Cole and Durham, 2007) As Elson (1994) observed: "The ability of money to mobilise labour power for 'productive work' [paid by the market] depends on the operation of some non-monetary set of social relations to mobilise labour power for reproductive work." (p. 40). Unpaid labour at home then becomes the backdrop to the paid work in the market that acknowledges the unpaid (mostly) female labour, albeit indirectly, through the notion of a 'family wage.'

The concept of generation has several dimensions, one of which is the commonly noted dimension of time (age) as reflected in the categories of childhood, adulthood and old age. These categories are to some extent driven by the biological cycle of human development, for example the onset of puberty, but of more interest are the socially driven dimension of age such as the rite of passage into adulthood, marriage, work related events such as retirement, common experience (e.g. military service, education), etc. These experiences shape a generation and are important to the production and re-production/regeneration of cultural norms and mores, as one generation transmits its culture to another. This transmission is about continuity and change at the same time, as much as the transition from a 'traditional' to 'modern' society is about change that often maintains links to the past. It is the balance between this continuity and change that is going to define the future of inter-generational relationship in the MENA region.

The next section will be dealing with some of the long-term implications of the changing demography of the MENA. 


\section{Generations and demographic change in MENA}

Several major developments are changing the demography of the MENA countries which are now at different phases of their demographic transition. Earlier mortality decline followed by fertility decline have led to a gradual decline in the rate of population growth in the region that however varies across countries. (Roudi-Fahimi and Mederios, 2007) Yet earlier high growth of population has resulted in a young age structure (those in $15-24$ age group constitute about 20 per cent of population in the region) that has ensured a growing population despite a declining fertility rate across the region. By 2050 most countries in the region are forecast to have anywhere between 1.3 to 1.7 times more people than in 2007. Life expectancy in the region has also increased to 70-73 years in most countries in the region. (UN, 2013)

Other notable demographic changes are related to family formation and migration. The region has witnessed an increase in the use of modern contraceptives, increase in age of marriage and a reduction in family size. The increase in age of marriage has been attributed to the rising cost of setting up a home, mainly due to rising property prices, high unemployment among the young people and high incidence of poverty among the working population. Among other reasons for late marriage is the increased autonomy of women, due to their increased educational level. (Roudi-Fahimi and Mederios, 2007)

Family size in the region has decreased to 5.4 in urban and 6.1 in rural areas, with the family size decreasing with the increase in the education of the head of family. Moreover, family size is even smaller in nuclear families - 4.7 persons per nuclear family. Nuclear families comprise 85 per cent of all families in the region. A further development is the number of children per family that in urban areas stands at 2.4 and in rural areas at 3 , that again declines with the increase the education of the head of family. In the foreseeable future the family size is going to be stable given the combined effects of declining mortality and fertility moving in the opposite direction. These developments combined with the rising age of marriage and high youth unemployment ensures that there would be more adults at home, resulting in a stable dependency ratio. (Bongaart, 2001)

These changes are in line with the developments in other parts of the world. (See Table 1) The trend towards smaller families in developing regions follows the pattern observed in the developed countries in the 19th century, that has been attributed to adoption of some older methods family planning, urbanization (associated with lower fertility and mortality over time), 'modernisation' of life style and the move towards nuclear families, and above all the development of capitalism and its associated work patterns and family formation. (Bongaart, 2001, and Seccombe, 1983)

Table 1. Family size and number of children in developing regions by area of residence and education of head of family. (1980s)

\begin{tabular}{llllll}
\hline & Residence & \multicolumn{5}{l}{$\begin{array}{l}\text { Head of family } \\
\text { Education }\end{array}$} \\
\hline & Urban & Rural & None & Primary & Secondary \\
Asia & 4.9 & 5.4 & 5.2 & 5.2 & 5.2 \\
L. America & 4.6 & 5.0 & 4.7 & 5 & 4.4 \\
Near E./N.Africa & 5.4 & 6.1 & 5.9 & 5.7 & 5.0 \\
S.S. Africa & 5.1 & 5.3 & 5.2 & 5.3 & 5.0 \\
Number of & & & & & \\
Children & & 2.5 & 2.2 & 2.2 & 2.3 \\
Asia & 2.0 & 2.5 & 2.1 & 2.3 & 1.9 \\
L. America & 1.9 & 3.0 & 2.8 & 2.8 & 2.3 \\
Near E./N.Africa & 2.4 & 2.8 & 2.7 & 2.8 & 2.5 \\
S.S. Africa & 2.5 & . & & & \\
\hline
\end{tabular}


The last major demographic development in the region is migration and movement of labour, which crucially depends on the resource base of different countries. Despite popular perceptions, the region is quite heterogeneous in terms of resources, social and economic history. According to Richards and Waterbury (1996), MENA countries can be divided into several groups based on their natural and human resources. The first are the small countries that are very rich in oil or gas such as Libya, Kuwait, Qatar, UAE or have limited oil reserves like Oman and Bahrain. These have very small markets and little resources to diversify their economies, notwithstanding the fact that Dubai in UAE has been successful in developing a vibrant entrepot sector and, more recently, a tourist industry. Immigrant labour from poorer countries of the region as well as the Indian subcontinent has been key to the development of these sectors in Dubai as well as the economy of this group of countries. Then comes the oil industrialising countries of Iran, Algeria, Saudi Arabia and Iraq (whose fortune has dramatically changed since the US led invasion in March 2003) that have substantial oil reserves and other natural resources as well as sufficiently large population allowing them to diversify their economies. Iran and Algeria have been more successful industrialisers than other countries in this group though they still rely heavily on oil for their export earnings. The third group consists of the 'small' natural resource poor countries of Israel, Jordan, Syria and Tunisia that have been relatively successful in diversifying their economies through education and skill development and developing a sizeable manufacturing sector. The fourth group includes the newly industrialising countries (NICS) of Turkey, Egypt and Morocco that have either no oil (Turkey and Morocco) or insufficient amount (Egypt) that cannot be relied on for a long-term growth strategy. All have sizeable populations and reasonably strong agricultural sector with potential for future growth. In the poorest category are Sudan and Yemen, who rely on mainly agriculture and some oil exports, and remittances of those who work in the oil rich countries of the region and elsewhere. It has to be noted that the above taxonomy should not be treated like a map with clear demarcated boundaries, but as a general guide as to the constraints and potentials of different MENA countries.

The heterogeneity of the MENA is reflected in the incidence of poverty in different countries Using the headcount poverty measure of a-dollar-a-day (or more) poverty is rife in the labour abundant and resource poor countries. But poverty is also present in the large resource rich and industrializing countries of Iran and Algeria (Iqbal, 2005, Messkoub, 2008). The incidence of poverty however is very sensitive to the head count poverty rate. For example in Egypt it rises from less than 5 per cent of population at a-dollar-a-day to above 40 per cent at two-dollar-a-day. (Iqban, 2005, p. 18) Whatever the merit or otherwise of poverty rate, this reveals the vulnerability of population to small shocks to their resource base. This suggests that traditional headcount poverty rates should be complemented by some indicator of vulnerability when it comes to the assessment of inter-generational support and social policy design. The other aspect of poverty is its regional spread. In all countries referred to in Iqbal's (2005) study, rural headcount poverty rates are higher in rural areas than in urban areas.

In the MENA region as elsewhere in the world, national and international migration has always been part of the household strategy to improve the life chances of its members. Table 2 provides a snap shot view of migration in MENA. Almost all labour abundant countries have sent large number of migrants to other countries, as indicated by the negative net migration figures. The reverse is true for labour deficit countries that have recorded positive net migration. It should be noted that these figures conflate international migration, whether within or outside the MENA region, and do not account for internal migration.

In concluding this section several observations are in order. Demographic changes are taking place in the MENA region at a very fast pace - families are getting smaller, more families are of nuclear type, and less children are borne. In resource poor, labour abundant countries poverty is a major problem for a large section of population. Migration has been an important part of family and individual strategy to cope with poverty and improving life chances for the family and individual. 
The question of inter-generational support is in part about the demographic balance between generation within the family and society at large, and in part about resources of the family and societal distributional.

Table 2. Net migration in MENA, 1995-2010.

\begin{tabular}{|c|c|c|c|c|}
\hline Country & $1995-2000$ & 2000-2005 & $2005-2010$ & Net Migration Rate $\begin{array}{c}2005-2010 \\
\text { per } 1000\end{array}$ \\
\hline Bahrain & 19 & 25 & 448 & 90 \\
\hline Iran (Islamic Republic of) & 687 & 126 & -186 & -1 \\
\hline Iraq & -18 & -580 & -150 & -1 \\
\hline Israel & 245 & 103 & 274 & 8 \\
\hline Jordan & -188 & -94 & 203 & 7 \\
\hline Kuwait & 125 & 162 & 278 & 22 \\
\hline Lebanon & 0 & 100 & -13 & -1 \\
\hline Occupied Palestinian Territory & 70 & -190 & -90 & -5 \\
\hline Oman & -229 & -50 & 153 & 12 \\
\hline Qatar & 43 & 170 & 857 & 133 \\
\hline Saudi Arabia & -877 & 1726 & 1056 & 8 \\
\hline Syrian Arab Republic & -130 & 548 & -56 & -1 \\
\hline Turkey & -150 & -100 & -50 & -0 \\
\hline United Arab Emirates & 469 & 780 & 3077 & 106 \\
\hline Yemen & -100 & -100 & -135 & -1 \\
\hline Northern Africa & -1862 & -1667 & -1020 & -1 \\
\hline Algeria & -140 & -140 & -140 & -1 \\
\hline Egypt & -946 & -371 & -347 & -1 \\
\hline Libyan Arab Jamahiriya & -20 & -20 & -20 & -1 \\
\hline Morocco & -500 & -614 & -675 & -4 \\
\hline Sudan & -227 & -532 & 135 & 1 \\
\hline Tunisia & -56 & -81 & -20 & -0 \\
\hline Western Sahara & 27 & 90 & 48 & 20 \\
\hline
\end{tabular}

\section{Net migration in 1000 \\ Migration rate per 1000 destination population}

Source: Adapted from: UN (2013) World Population Prospects: The 2010 Revision. NY, US: UN Population Division.

\section{Family and inter-generational support}

In broadest terms a family's economic resources are based on self/employment, property income (based on financial and other income earning assets), remittances, and state support in the form of direct income support or subsidy to basic consumption goods, health and education. A combination of these resources determine inter-generational support a family can offer to its members.

In this paper we will not deal with property income, since information on distribution of assets is difficult to obtain. More important and judging by the incidence of poverty in the labour abundant countries, it can be safely assumed that the great majority of the people in these countries do not have access to assets that can generate sufficient income for them.

Employment as a major source of family income has come under great stress in recent years In 2010, unemployment in the MENA region was about 10 per cent and the figure for women was 15 per cent. Youth unemployment is particularly high in the region. In 2010, it stood at 27 
per cent, with the figure even higher among the educated youth. Female unemployment, in particular among the educated, is quite high: 40 per cent. Youth unemployment is not confined to the MENA region and many countries in Europe have record figures since the financial crisis of 2009. For example, Spain registered a youth unemployment rate of 46 per cent in 2012, Greece, 42 per cent and Cyprus 20 per cent. (ILO, 2012) But what distinguishes youth unemployment in MENA is the fact that figures have been high well before the financial crisis and are a structural feature of the labour market in the region. Job creation has hardly kept pace with a rising youth population as they enter the labour force. (Messkoub, 2009)

Another aspect of the labour market in the region is low pay and low return to labour, and vulnerability and insecurity of many jobs. In most MENA countries there are no unemployment benefits and most poor people cannot 'afford' to be unemployed. The working poor are a sizeable proportion of the working population. In late 1990s working poor accounted for 12 per cent of working population in Tunisia, with the figure rising to 30 per cent in Algeria, and staggering figures of 71 per cent in Egypt and 74 per cent in Yemen. (See table 3)

Table 3 - Working Poor as a proportion of working population in selected MENA countries (late 1990s)

\begin{tabular}{ll}
\hline Country & $\%$ \\
\hline Yemen & 74 \\
Egypt & 71 \\
Algeria & 30 \\
Morocco & 23 \\
Jordan & 13 \\
Tunisia & 12 \\
\hline
\end{tabular}

\section{Source: ILO, 2012.}

The reasons for why people remain poor despite their hard work are varied and complex. Unequal distribution of assets and power play an important role in holding back the working poor from claiming their just and fair share of what they produce. Many small farmers do not have access to sufficient land or other agricultural inputs to improve their productivity. The selfemployed people in urban areas often lack the resources to expand and improve their operations. In short low productivity is at the heart low return to labour in many sectors. At the same time weak trade unions and poor implementation of labour laws do not empower workers to ask for higher wages and better conditions. Absence of or low minimum wage is another reason for the low return to labour in many countries.

But it is the structural reasons for low return to labour that should be of most concern to policy makers. Unequal distribution of land, low skills, low capital investment, inefficient and often outdated technology will all lead to low productivity and low return. The financial and banking sector is also not geared to the needs of the small producers and the self-employed poor people. The micro-credit 'revolution' that was supposed to fill this gap has hardly changed the fortune of the great majority of the poor. What is needed is to tackle the problems of unequal distribution of power and assets that requires some fundamental political changes and more commitment by the state to improve education and skill levels as well as helping to upgrade technology in agriculture and industry.

It should be clear that the great majority of families do not have adequate resources to meet their needs and provide adequate inter-generational support. Given the chronic and structural poverty in the labour abundant and resource poor countries inter-generational support has to go beyond families and take the broader perspective of societal inter-generational relations. In the labour deficit and resource rich countries the issue of inter-generational support within families poses several problems that again calls for a societal approach to inter-generational relationship. The first is the issue of income inequality in these countries. Only the small and very rich oil and 
gas producing countries can maintain sufficiently high income transfers to, as well as providing high level of health and educational services for their nationals to ensure adequate intergenerational support by families. In most of the larger oil exporting countries inequality in the distribution of income and assets, unemployment and inadequate public services have for long been the main reasons for public discontent. Lack of or inadequate democratic structure and governance to ensure accountability, participation and transparency have also seriously limited the voice and the negotiating power of the majority of population in MENA. Finally, there is the all important issue of the rights of international migrants who have been of critical importance to the economy of labour deficit countries, and would become even more important in the future as population ages in these countries. It is no exaggeration to state that the inter-generational support in areas of health, education, housing and care, to name but a few, in labour deficit countries cannot be maintained without the availability of migrant labour. It is in this context that we turn to societal inter-generational support and social policy.

\section{Social policy, families and inter-generational support}

At micro-level family is the main channel through which various types of inter-generational support are provided, that contribute to production and re-production of at micro and macro levels. Families however are not homogenous and are divided along social and economic lines that determine their capacity to provide inter-generational support. As noted earlier given the high incidence of poverty in many of the MENA countries and inadequacy of family resources there is a need for social policy measures that would supplement family resources and support the broad developmental agenda and ensure societal inter-generational support.

The most basic objective of any state intervention is to maintain and increase families' resource base. In this context state intervention for inter-generational support could be linked to market for: goods (e.g. provision of necessities such as health, education, housing and basic food stuff), labour (e.g. job creation and labour issues) and money (e.g. provision of credit for businesses).

More specifically family budget constraint will be improved by first de-commodifying (through regulation and intervention in the market) the basic necessities of life. Decommodification does not necessarily mean free provision of goods and services. It could take different forms like rent control, subsidized medicine and basic food, free primary schools, free vaccination, etc. Second, by improving the human capital of family through improved health and education, employability and income earning opportunities of the families will increase. Third, by maintaining labour demand through job creation by private and public sector and increasing labour force participation of women families will have more secure earning opportunities through employment.

Implementing the above policies would depend on the resource base of different countries. The resource rich and labour short countries obviously have an advantage over the others by having large foreign reserves and no financial constraint to finance universal welfare programmes. The issue of inter-generational support is not a problem, neither at family level nor at national level for these countries. Despite the existence of some youth unemployment in these countries, family resources and state spending are sufficient to maintain good standard of living for the young. But problems of these countries is rooted in their demography - they are short of labour to maintain and develop their economies almost in all sectors and skill levels, a gap that is filled by immigrant labour. With investment in education and skills in these countries, it is hoped that the shortage of skilled labour may somewhat be lessened but in other areas labour shortages will continue, particularly in the care, construction and service sector. It would also be expected that demographic transition and population ageing will increase the need for interngenerational support, that with the most likely increase in the labour force participation of native women in some countries would generate a stable demand for migrant labour. In short inter-generational support in resource rich, labour deficit countries will require a stable and steady flow of migration. 
Whether this demand for labour will be fulfilled depends on the demographic situation and economic development in the labour abundant and the Asian countries (e.g. Bangladesh, Nepal, India, Philippines) that have been sending migrants to the MENA region for decades. Demographic transition is already underway in many of these countries that if combined with steady economic development will increase demand for labour and improve pay and conditions in these countries that would lower the propensity to migrate to the labour deficit MENA countries. To ensure a steady flow, the migrant receiving countries have to change their migration policy that would not only improve pay and conditions for the low skill migrants but also introduce some flexibility in the labour market. The current 'guardianship' ('kefalat') system that ties the immigrant to the sponsoring or 'guardian' ('kafil') employer has led to labour market segmentation (defined as a market divided by non-competing groups) in labour deficit countries, where citizens and high skilled workers have far more rights and enjoy better living standards than the low skilled migrants in construction, service and other sectors. Migrants also have very little right to long term residence in the receiving countries. Low skill migrants could easily be abused by unscrupulous employers re-enforcing market segmentation.

What is needed is an integrated labour market where labour law and rights could be applied to all in order to improve pay and conditions of immigrant labour. MENA countries should improve residency rights and make the 'kefalat' system more flexible by allowing migrants to move between employers, at least after a minimum period of working for their sponsoring employer. This would improve the flexibility in the labour market and stabilise the migrant labour and bring the labour deficit countries closer to some of the best practices in other countries. Moreover, the labour deficit countries should also plan for permanent immigration in order to solve their long-term labour imbalance. It is highly unlikely that the labour deficit countries can close the gap between their labour demand and national labour supply in the near future and given their demographics. One of the best policies in the area of immigration is admitting migrants on the basis of skill shortages that would give the right to enter and reside temporarily that could in due course lead long-term residency. MENA may be far from a skill shortage immigration programme (as in Australia or US), but a debate has to start to improve the existing immigration system and plan for the labour demands of the future.

The next group of countries to consider is resource rich and labour abundant countries. These countries have experienced improved human development for their nationals through basic programme in the areas of health (for example vaccination and basic preventive care), education, subsidized food, etc. The scope and scale of such provisions, however, vary greatly across different countries. Considering their large population and limited oil income most of them are dependent on high oil prices to fulfill their welfare plans.

Ensuring that families can fulfill their inter-generational support in resource rich labour abundant countries governments have to maintain the real income of families by controlling inflation and cost of two major items of expenditure - housing and curative health care. This calls for prudent expenditure of the oil money in the country to avoid inflationary pressure, and partial de-commodification of health and housing. Another major concern in the medium term is high youth unemployment in these countries that requires active job creation policies, involving both public and private sector.

Resource poor and labour abundant countries face many more hurdles than the other groups of countries. The human development record in the resource poor countries is varied and depends on the social class - obviously the richer classes enjoy better standard of living and higher human development. These countries face chronic foreign exchange constraints and fiscal problems that would limit their policy space to carry out much needed social policy measures in areas of health and education. Like elsewhere in the MENA region, they also suffer from high youth unemployment. How have families coped with their low living standards, poverty and vulnerability?

As noted earlier, migration to richer countries in the region and beyond has helped to 
improve living standards for migrant sending families. Remittances have been an important contributor to family income and a source of foreign exchange for the government. Considering the level of poverty and high unemployment in the region families have limited scope for inter-generational support, without relying on state subsidies to basic food stuff, education and health. Social policy measures in these countries to ensure family based and societal inter-generational support here are no different from the resource rich and labour abundant countries, except that the needs are bigger and finances more limited in the resource poor countries.

However, states could still do a lot in the resource poor countries by focusing on some key areas like universal and free preventive and primary health care, as well as school level education, and de-commodifcation through intervention in the market for curative health care, housing and higher education

Job creation and job protection should again be on the agenda. Whilst state in the resource poor countries have a lot less economic power than in the rich countries they can contribute to job creation by providing support to the private sector through appropriate tax and subsidy policies, and by training and educating the work force to meet the skill needs of the private sector.

It is clear that countries of the region, resource rich or poor and labour abundant or short, have been related to one another for centuries through trade, migration, capital flows and certain common cultural traits such as religion, and in the case of most countries the Arabic language. These links do give a regional dimension to the issue of inter-generational support. Migration and remittance flows demonstrate that inter-generational support already relies on regional economic linkages.

Yet, by all accounts, the region is very poorly integrated. Regional trade accounts for less than 10 percent of total trade in the Arab MENA, with the Maghreb countries having the lowest share of intra-regional non-oil merchandise trade. Low regional integration, according some studies, has led to the potential loss of 1-2 per cent growth of GDP. Higher GDP growth is particularly important for creating jobs for the 20 million or so unemployed people in the region and for the new comers who enter the labour market at an annual rate of 3.4 per cent. (World Bank, 2013, see also Hakimian and Nugent, 2004)

Strengthening existing regional links in relation to migration and labour mobility could contribute to inter-generational support. This could be helped by the integration of labour market across the region, initially by reducing regulation in hiring non-nationals, and by de-politicising migration of labour. The future generations are going to live in the same region and regional economic cooperation is needed if inter-generational support were to continue.

\section{Acknowledgment}

I would like to thank the Qatar Foundation for organizing the conference "Protecting Arab family from poverty: employment, social integration and intergenerational solidarity" (Doha, 2-3 June 2013) and inviting the author to present this paper. May I thank Ms Amina Mesdoua for her efficient organization and encouragement to write this paper. I would also like those present at the conference for their comments during the presentation of an earlier draft. Finally, this paper draws on my earlier works on employment, poverty and social policy in the MENA region.

\section{References}

- Abdelrahman, M. M., 2001. State and civil society relations: the politics of Egyptian NGOS PhD thesis. The Hague, NL: Institute of Social Studies,

- Auer, P. and Islam, R.,2006. Economic Growth, Employment, Competitiveness, and Labour Market Institutions. In: XX Global Competitiveness Report 2006-07. Basingstoke (UK): Palgrave Macmillan: The World Economic Forum., pp. 105-116.

- Bongaarts, J. (2001) Household Size and Composition in the Developing World. New York: Population Council, report no. 144 
- Brandsma, J. and Bajourjee, D., 2004. Microfinance in the Arab World. New York: U.N. Capital Development Fund.

- $\quad$ Broude, Tomer, 2010. 'Regional Economic Integration in the Middle East and North Africa: A Primer,' in C. Herrmann and J.P. Terhechte (eds.), 2010, European Yearbook of International Economic Law, European Yearbook of International Economic Law. Berlin Heidelberg: Springer-Verlag.

- Cavallo, E. and Izquierdo, A. (ed.) (2009) Dealing with an International Credit Crunch: Policy Responses to Sudden Stops in Latin America. Washington DC: Inter-American Development Bank.

- Cole, J. and Durham, D. (2007) Generation and Globalization: Youth, Age and Family in the New World Economy. Bloomington and Indianapolis, US: Indiana University Press.

- Financial Times, 2010. 'The dog that hasn't barked' in International Business Insight, p. 2. October 22.

- $\quad$ Iliffe, J., 1987. The African poor: a history. Cambridge: CUP

- ILO, 2005. World Employment Report 2004-05: Employment, Productivity and Poverty. Geneva: ILO.

- ILO, 2006. Employment Poverty Linkages and Policies for Pro-poor Growth in Jordan (19902003). Geneva: ILO. Second Draft. Mimeo (restricted document)

- ILO, 2007. http://www.ilo.org/public/english/employment/strat/yen/publ/recomm. htm\#3.4 (Accessed April 2007.)

- ILO, 2009. Key Indicators of the Labour Market (KILM). Fifth edition. Geneva: ILO

- ILO, 2012. Global Employment Trends for Youth 2012. Geneva: ILO.

- $\quad$ (Accessed 20 May 2013: http://www.ilo.org/wcmsp5/groups/public/---dgreports/--dcomm/documents/publication/wcms_180976.pdf)

- Iqbal, F., 2005. Sustaining Gains in Poverty Reduction and Human Development in the Middle East and North Africa. Washington, D.C.: World Bank.

- Islam, I., 2005. Managing without Growth: Challenges Confronting the Syrian Labour Market. Geneva: ILO. Unpublished manuscript

- Islam, I., 2009. The Global Economic Crisis and Developing Countries: Transmission Channels, Fiscal and Policy Space and the Design of National Responses. Geneva: ILO, Employment Sector, Working Paper No. 36.

- Islam, R., 2004. The Nexus of Economic growth, Employment and Poverty Reduction: An Empirical Analysis. Geneva: ILO

- Karshenas, M. and Moghadam. V. (eds.), 2006. Social Policy in the Middle East and North Africa. Basingsoke (UK): Palgrave Macmillan and Geneva: UN Research Institute for Social Development.

- $\quad$ Khan, A., 2001. Employment Policies for Poverty Reduction. Geneva: ILO

- Marx, K., 1990. Capital: a Critique of Political Economy. Translated by Ernest Mandel Harmondsworth (UK): Penguin.

- McKinley, T. and Mehran, F., 2006. Strengthening the Employment Impact of an MDGBased Development Strategy for Yemen. Brazil: UNDP, International Poverty Centre, Country Study No. 4, September.

- MENAFN, 2010. http://www.menafn.com/qn_news_story_s.asp?Storyld=1093365023 (Accessed 8 August 2010)

- Messkoub, M., 2006. 'Constitutionalism, Modernization and Islamization: A Political Economy of Social Policy in Iran' in Karshenas and Moghadam (eds.), 2006.

- Messkoub, M., 2006. Social Policy in Iran in the 20th Century, Iranian Studies, 39(2)

- Messkoub, M. 2008. 'Social Policy in Iran: Islamic or Secular?' Policy World.

- Spring. Published by the British Social Policy Association.

- Messkoub, M., 2008. Economic Growth, Employment and Poverty in the Middle East and North Africa. ILO Working Paper Series, No. 19

- Messkoub, M., 2009. 'The Impact of Global Financial Crisis on Employment and Poverty in the MENA Region.' Paper presented at the UN-ESCWA expert meeting on the global 
financial and economic crisis: The Social Impact and Responses in the Region. 8 December, Beirut, the Lebanon.

- Messkoub, M., 2011. 'Crisis, Employment and Poverty in the Middle East and North Africa,' in Peter A.G. van Bergeijk, Rolph van der Hoeven and Arjan de Haan (eds), 2011. The Financial Crisis and Developing Countries. Cheltenham (UK): E.Elgar.

- Mina,Wasseem, 2010. 'Institutional Reforms Debate and FDI Flows to MENA Region: Is Debate Relevant?' Http://www.hecer.fi/Conferences/NCDE_2010/papers/Mina.pdf (Accessed 8 August 2010)

- Miniesy/Nugent/ Yousef, 2004. 'Intra-Regional Trade in the Middle East: Past Performance and Future Potential', in H. Hakimian and J. Nuggent (eds.), 2004. Trade Policy and Economic Integration in the Middle East and North Africa: Economic Boundaries in Flux.

- Mirkin, B. (2013) Arab Spring: Demographics in a region in transition. Arab Human Development Report Research Paper Series. New York: UNDP

- Osmani, S.R., 2003. Exploring the Employment nexus: Topics in Employment and Poverty New York: UNDP and Geneva: ILO.

- Osmani, S.R., 2005. The Role of Employment in Promoting the Millenium Development Goals. New York: UNDP and Geneva: ILO.

- Richards, A. and Waterbury, J. 1990. A Political Economy of the Middle East: State, Class and Economic Development. Boulder, Colorado: Westview Press.

- Roudi-Fahimi, F. and Mederios, M. (2007) Challenges and Opportunities - The Population of the Middle East and North Africa. Population Reference Bureau

- Population Bulletin, Vol. 62, No. 2, June. Washington, DC, US: Population Reference Bureau.

- Salehi-Isfahani, Dj. (2010) Human Development in the Middle East and North Africa UNDP Human Development Research Paper 2010/26. NY, US: UNDP

- Seccombe, W. (1983) 'Marxim and demography,' New Left Review, No. 137

- Subbarao, K., 2003. Systemic Shocks and Social Protection: Role and Effectiveness of Public Works Programs. Washington, D.C.: World Bank, Social Protection Discussion Paper Series.

- Sundaram, K. and Tendulka, S.D. 2002. The working poor in India: Employment-Poverty linkages and Employment Policy Options. Geneva: ILO

- Tzannatos, Z., 2009. The Global Financial, Economic and Social Crisis and the Arab Countries: a Review of the Evidence and Policies for Employment Creation and Social Protection. Beirut: ILO Regional Office for Arab States.

- UNIDO (United Nations Industrial Development Organization), 2001. Integrating SME subglobal value chains: Towards partnership for development. Vienna: UNIDO.

- UNDP, 2012. Arab Development Report 2011. Cairo: UNDP.

- UN, 2013. World Population Prospects: The 2010 Revision. NY, US: UN Population Division. (Accessed: 8 May 2013)

- World Bank, 2009. 2008 Economic Development and Prospects: Regional Integration for Global Competitiveness. Middle East and North Africa Region. Washington DC: IBRD.

- World Bank, 2011. World Development Report, 2011.

- World Bank, 2013. 'Trade Integration in the Middle East and North Africa'.

- http://web.worldbank.org/WBSITE/EXTERNAL/COUNTRIES/MENAEXT/EXTMNAREGTOPP OVRED/0,contentMDK:22492441 pagePK:34004173 piPK:34003707 theSitePK:497110,00. html. (Accessed: I August 2013.) 